\title{
ВЕЛИКАЯ ОТЕЧЕСТВЕННАЯ ВОЙНА: МОДУСЫ ПАМЯТИ
}

\section{THE GREAT PATRIOTIC WAR: MEMORY MODES}

\author{
A. Larionov \\ M. Dvorkovaya \\ E. Kurenkova
}

Summary: The article is devoted to the study of specific models of the commemoration of the Great Patriotic War in the states formed after the collapse of the USSR. The aim of the article was to build a single multidimensional model of the post-Soviet memorial space of war as a result of the interaction of public sentiments and state historical policy. The study revealed a high degree of participation of post-Soviet political regimes in the formation of a particular image of war in the mass consciousness of citizens.

Keywords: World War II, historical politics, historical memory, "memory wars".

Б есспорен тот факт, что бытие государств и народов протекает в рамках исторического времени. Следовательно, поддержание национально-государственной идентичности и легитимация политической субъектности возможны только с опорой на сложившуюся в данном обществе культуру памяти. В свою очередь культура памяти (которая всегда конкретна, то есть мыслима в контексте определённого социума) выражается в ритуалах и нормах коммеморации и в полиморфном культурно-историческом нарративе. Поскольку культура памяти сама является частью социальной коммуникации и темпорального пространства, постольку она дуалистична. Оказывая влияние на общественное сознание, нередко задавая направленность государственной политике, она, в то же время, сама подвержена изменчивости под их влиянием. В силу чего также может становиться предметом исторического исследования.

В процессе исследования предполагается отыскать ответы на следующие вопросы: какие модусы социальной памяти о Великой Отечественной войне существуют в настоящее время на постсоветском пространстве? Как войны памяти отражаются на социальном развитии постсоветских обществ?

Исследований по проблемам содержания и трансформаций исторической памяти в отечественной и зарубежной научной вселенной насчитывается значи-
Ларионов Алексей эдиславович

К.и.н., доцент, Московский государственный областной университет; Технологический университет, г. Королев allar71@yandex.ru

Дворковая Марина Васильевна К.и.н., Московский государственный областной университет marinadvorkovaya@yandex.ru Куренкова Евгения Алексеевна К.и.н., дочент, Московский государственный областной университет

kurenkovagane@mail.ru

Аннотация: Статья посвящена исследованию конкретных моделей коммеморации Великой Отечественной войны в государствах, образованных после распада СССР. Целью статьи было построение единой многомерной модели постсоветского мемориального пространства войны как результата взаимодействия общественных настроений и государственной исторической политики. В ходе исследования была установлена высокая степень участия постсоветских политических режимов в формирования того или иного образа войны в массовом сознании граждан.

Ключевые слова: Великая Отечественная война, историческая политика, историческая память, «войны памяти».

тельное количество, нельзя сказать, что из них можно получить исчерпывающие ответы на те вопросы, которые были сформулированы выше. Что и обосновывает актуальность нашего небольшого исследования.

Популярным мнением после распада Советского Союза стало утверждение об обретении народами бывших союзных республик национальной независимости как важнейшего условия будущего расцвета культуры и повышения качества жизни во всех областях. Именно подтекст улучшения жизни подразумевался представителями республиканских элит, успешно разыгрывавших националистическую карту. Однако, существуют и иные оценки, представляющие подлинные намерения обновлённых политических элит в менее выгодном для них свете. В частности, основываясь на печальной эмпирике социального реформирования конца XX века в бывшем СССР, А.С. Панарин делает следующий вывод: «Элиты, пожелавшие стать глобальными, не только отказались от национальной идентичности и от защиты национальных интересов. Они отказались разделять с собственными народами тяготы существования, связанного с заповедью «в поте лица своего добывать хлеб насущный». Элиты заявили о своем праве свободно мигрировать из трудных в легкие, привилегированные пространства, из сфер, требующих напряжения и ответственности, - в прекрасный новый мир, где царят легкость и безответственность» [4]. 
Следовательно, ревизия исторической политики предстаёт как инструмент манипуляции общественным мнением. В данном случае необходимо учитывать следующее. Для Советского Союза официальный дискурс памяти о Великой Отечественной войне играл роль краеугольного камня не только в здании идеологии наряду с датой Октябрьской революции 1917 года, но и в конструировании универсалистской по характеру и общесоюзной по охвату национально-государственной идентичности. Демонтаж СССР проводился сколь под антикоммунистическими, столь же и под националистическими знамёнами. Отсюда вполне закономерно вытекало стремление тотальной ревизии исторической памяти, прежде всего в отношении знаковых, символических событий. Великая Отечественная война на роль объекта такой тотальной ревизии подходила идеально. Цели же, при этом, преследовались самые что ни на есть прагматические в подавляющем большинстве случаев. В наибольшей степени это стало характерным для воссозданных прибалтийских государств (Латвия, Литва, Эстония) и Украины. Молдова обладает собственной спецификой памяти о войне. В минимальной степени разрыв с советским наследством оказался характерен для Белоруссии. Республики Закавказья и Средней Азии оказались в меньшей степени вовлечены в «войны памяти», однако постепенно и в них сложилась собственная версия участия в Великой Отечественной войне и оценок этого события с позиций новейшей национальной истории и актуальных потребностей новой власти. Дуалистичная ситуации в области исторической политики и памяти о Великой Отечественной войне сложилась в России. Таким образом, можно констатировать, что некогда единый советский дискурс памяти о Великой Отечественной войне после 1991 года подвергся быстрой дезинтеграции и претерпел распад. Память о войне не просто оказалась «растащена по национальным квартирам», но также существенно, порой на $180^{\circ}$ изменила своё содержание в плане интерпретаций и оценок одних и тех же событий.

С наибольшей силой в постсоветском пространстве памяти проявился модус ревизионизма, который нередко сводился к абсолютной инверсии оценок значимости событий Великой Отечественной войны. Наиболее показательным модусом памяти о войне являются учебники истории. Максимальная инверсия мемориального образа войны в сознании подрастающего поколения складывается в украинских и прибалтийских учебниках. Несколько мягче выстраивается образ Великой Отечественной войны в учебниках Молдавии. Договор о ненападении СССР и Германии трактуется как «сговор двух диктаторов», а освобождение территории Молдавии от фашистов - как «новая оккупация» [5, с. 429]. Иными словами, в сознании будущих граждан этих государств закладываются стереотипы негативного отношения к Советскому Союзу, а шире - к исторической России как некоей извечной угрозе суверенитету стран и народов. В жертву данному аксиологическому приоритету приносятся соображения исторической правды. Властные дискурсы в отношении новейшей истории своих народов в данном случае оказываются продиктованы сиюминутной конъюнктурой. Интерес легитимации власти посредством инверсионного разрыва с советским наследием и националистического угара превалирует не только над исторической действительностью, но и над критериями добра и зла в их метафизической трактовке. Ведь нацизм является злом в различных системах координат - от коммунистической до ультра-либеральной идеологии. Тактический выигрыш грозит обернуться стратегическим проигрышем в исторической перспективе.

Затронутая в настоящей статье проблема, с одной стороны, слишком актуальна, с другой стороны - слишком сложна и обширна, чтобы можно было рассчитывать исчерпать её в рамках одной публикации или хотя бы предложить ту объяснительно-оценочную модель, которая может удовлетворить всех тех, кто заинтересован в её обсуждении. Следовательно, продолжение анализа и столкновение мнений являются детерминантными и ожидаемыми процессами. В современном научном пространстве можно констатировать постоянное соперничество методологических подходов - к истории вообще, и к интеллектуальной истории - в частности. Потому, любому автору предстоит делать ответственный выбор между предлагаемыми вариантами методологии и конкретными методами анализа фактов, и даже при выборе стиля повествования. Например, Аллан Мегилл одним из ключевых критериев исторического нарратива полагает сенсационность: «Если у кого-то возникает желание писать историю, то нужно попытаться найти вещи, с точки зрения здравого смысла удивительные. Если же историк остаётся в пределах структуры памяти, то наиболее вероятным результатом станет не удивление, а подтверждение»[3, с. 132.]. Применительно к политике и модусам памяти о Великой Отечественной войне может сложить впечатление, что некоторые авторы и политические деятели буквально взяли на вооружение данную эпистемологическую установку американского учёного. Ведь попытки тотального ревизионизма исторической памяти о войне, сопряжённые с реабилитацией и апологией деятелей и движений откровенно фашистского толка действительно удивляют и даже повергают в шок массовое сознание. Но ведь изумление - не синоним и даже не признак истинности. Более того, именно на примере памяти о войне мы видим, что погоня за сенсационностью текста способна строиться на гигантских искажениях исторической правды - вплоть до прямого фактологического и источниковедческого подлога. Дискуссии вокруг интерпретаций и оценок Великой Отечественной войны будут продолжать ещё и потому, что в современном обществе, существующем в формате «гло- 
бальной деревни» по выражению Маршала Мак-Люэена, с мгновенным обменом информацией в режиме онлайн [2, с. 6], темпоральный режим модерна уже распался. Об этом блестяще говорит Аллейда Ассман.в одной из своих работ [1].

По всей вероятности, обозначенные модусы памяти о войне продолжат своё сосуществование, как бы ни хотелось адептам каждого из них, чтобы именно его образ прошлого восторжествовал полностью и безоговорочно над остальными. Проводя аналогию с самим предметом споров - войной 1941-1945 гг., никому из оппонентов в пространстве социальной памяти не удастся добиться абсолютной победы и водрузить знамя своего мемориального лагеря над развалинами чуждых мировоззрений. В таком ракурсе историческая политика правящих элит на постсоветском пространстве должна ставить перед собой реалистические цели, которые определяются не столько директивно, сколько в процессе конвенционального социального проектирования, но с непременной опорой на достоверные источники военного времени и высшие традиционные ценности и подлинные интересы своих народов. В любом случае, по мере дальнейшего развития социальных коммуникаций формирование как модусов памяти о войне, так и дискурсивных практик власти в отношении актуального прошлого будет немыслимо без общественного участия и обсуждения. Народы постсоветского пространства должны осознать свою коллективную ответственность за прошлое и за будущее. Только в этом случае можно надеяться на то, что в будущем войны памяти будут преодолены.

\section{ЛИТЕРАТУРА}

1. Ассман А. Распалась связь времён. Взлёт и падение темпорального режима модерна. М.: НЛ0, 2017.

2. Маклюэн Г.М. Понимание Медиа: Внешние расширения человека. М.: Кучково поле, 2003.

3. Мегилл А. Историческая эпистемология. М.: «Канон+» РООИ «Реабилитация», 2007.

4. Панарин А.С. Народ без элиты: между отчаянием и надеждой // https://e-libra.ru/read/138452-narod-bez-elity-mezhdu-otchayaniem-i-nadezhdoy.html Дата обращения 20.01.2020.

5. Чураков Д.О. «Войны памяти» и локальные конфликты современности // Преподавание военной истории в России и за рубежом. М.: Нестор-история, 2018.

(с Ларионов Алексей Эдиславович (allar71@yandex.ru), Дворковая Марина Васильевна (marinadvorkovaya@yandex.ru),

куренкова Евгения Алексеевна (kurenkovagane@mail.ru).

Журнал «Современная наука: актуальные проблемы теории и практики»

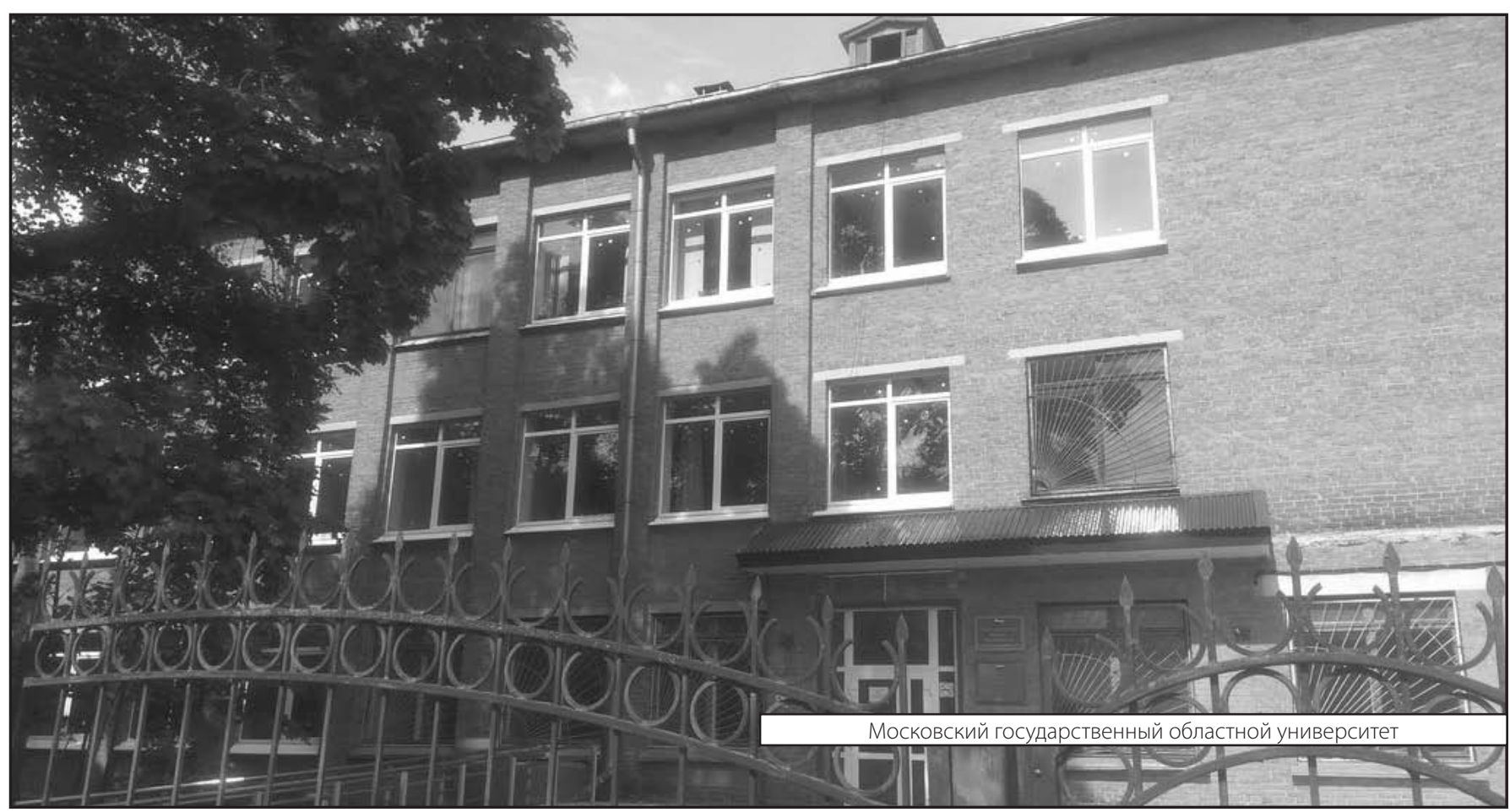

